\title{
Why Recognize? \\ Explaining Victorian Britain's Decision to Recognize the Sovereignty of Imperial Japan
}

\author{
Jacques E. C. Hymans
}

The question of why leading states recognize other states' sovereignty has attracted increasing attention in the IR literature. I analyze the important historical case of the sovereign recognition of Japan by the West in the 1890s and in particular by Great Britain, the most important Western power at that time. I argue that Britain's decision to fully recognize the sovereignty of Imperial Japan is best explained by a theoretical synthesis of English School and rationalist approaches. Britain's recognition decision was driven by a combination of genuine respect for legal propriety and its perceived material self-interest. In other words, Britain recognized Japan upon realizing that it would do well by doing good.

Key Words: state recognition, sovereignty, Great Britain, Japan, treaty revision

$\mathrm{W}$ hat causes leading states to recognize other states' sovereignty? The IR literature has become increasingly interested in answering this question in recent years. ${ }^{1}$ There are two main competing theoretical camps. On one side stand English School and constructivist scholars, who try to explain state recognition decisions as the product of the "logic of appropriateness." On the other

\footnotetext{
*Jacques E.C. Hymans (hymans@usc.edu) is associate professor of international relations at the University of Southern California and winner of the 2014 Grawemeyer Award for Ideas Improving World Order. He has published two award-winning books: Achieving Nuclear Ambitions: Scientists, Politicians, and Proliferation (Cambridge University Press, 2012) and The Psychology of Nuclear Proliferation: Identity, Emotions, and Foreign Policy (Cambridge University Press, 2006). Hymans has also published articles in Foreign Affairs, International Security, Security Studies, and many other publications. He is an editorial board member of International Studies Quarterly, the Nonproliferation Review, and the Korean Journal of International Studies.

Thanks to Ken Kawamura for research assistance especially with Japanese language sources, and to Tyler Curley, Christina Davis, Mikulas Fabry, Aaron Friedberg, Rustin Gates, Joseph Grieco, Kaoru Iokibe, Rieko Kage, David Kang, Jason Karlin, Tomoki Kuniyoshi, Byoung Won Min, Andrew Moravcsik, Naofumi Nakamura, Louis Perez, Paul Poast, Yu Suzuki, David Welch, and participants at the Korean Association for International Studies 2013 annual meeting, the Princeton security studies colloquium, and the University of Tokyo Japanese history group for their comments on an earlier version of this article. Research on this project was funded in part by the Sejong Fund of the Korean Studies Institute at USC.
}

${ }^{1}$ For a sampling of the richness and diversity of this new literature, see Agné et al (2013). 
side stand the rationalists, who try to explain state recognition decisions as the product of the "logic of consequences." In this article, I argue that treating these two logics as competing explanations is theoretically unnecessary and empirically unproductive. Drawing on a case study of Victorian Britain's recognition of the sovereignty of Imperial Japan, I argue for a synthetic approach that draws on both of the logics to better explain leading states' decisionmaking on this important issue.

The article is organized as follows. In the next section, I briefly summarize the IR theoretical debate on the causes of state recognition and non-recognition, and I present my idea for a theoretical synthesis. After that, I offer a new, archival document-based explanation of Great Britain's shift from imposing an unequal treaty on Japan in the 1850 os to signing an equal treaty with Japan in 1894. My key claim is that Britain's policy shift is best explained by a combination of the logic of appropriateness and the logic of consequences. Britain's recognition of Japan's sovereignty was made possible by the Meiji government's intensive and persistent Westernization efforts from the 1860 on onward. That was the impact of the logic of appropriateness. But the precise timing of Britain's recognition decision was significantly influenced by the increased ship purchasing budget of the Imperial Japanese Navy in the early 1890s, which coincided with the British government's intensifying desire to support the export trade of its naval shipbuilding industry. That was the impact of the logic of consequences. My focus on the importance of Japan's increased naval spending as a prod for Britain's recognition decision is an innovation for the historical literature on this topic. Having completed the historical narrative, in the concluding section I summarize the article's main findings and offer some ideas for future research.

\section{THEORIES OF RECOGNITION}

What does the current IR theoretical literature teach us about the causes of sovereign state recognition? ${ }^{2}$ Most recent scholarly work on the subject has adopted an "English School" approach (see, e.g., Fabry 2010; Jackson 2003, 14-15; Bull and Watson 1984). This approach views the sovereignty norm as the foundation of international society, without which there would be chaos. The existence of a set of legally independent states that are recognized as such by their peers is a

\footnotetext{
${ }^{2}$ Note that the matter in question here is the recognition of states as states, which can be distinguished from the recognition of the governments of those states.
} 
basic prerequisite for whatever order or predictability exists in the international system. Therefore, recognition decisions are a very serious matter. And this in turn means that leading states employ the logic of appropriateness in their deliberations on whether or not to accord sovereign recognition. If a political entity satisfies the standard normative criteria for international membership, then it will more or less automatically receive sovereign recognition; but if not, then not.

An alternative strand of the literature, by contrast, adopts a rationalist approach to the question of state recognition (Krasner 1999; 2013). This literature does not deny the existence of the sovereignty norm, but it does deny that the norm is the foundation of the international system. Instead, it depicts the norm as nothing more than a set of generic guidelines that can be taken off the shelf to lower the costs of policy formulation and implementation in the modal case of state-to-state interaction, but that can also be easily altered to suit a state's selfinterest - even while claiming that the norm has been respected. In short, states' claims to respect the sovereignty norm are a form of "organized hypocrisy." The logic of consequences (i.e., self-interest) regularly trumps the logic of appropriateness as a driver of leading states' decisionmaking on whether or how much sovereign recognition is to be granted. If the act of recognition provides adequate utility payoffs, then recognition will happen; but if not, then not.

In short, English School and constructivist scholars see acts of sovereign recognition as the precious application of acknowledged international normative principles, whereas rationalists see them as a strategic move by states in pursuit of their perceived material self-interest.

IR scholars working on the question of state recognition tend to suggest that the two logics are fundamentally at odds with each other. But is that really the case? In fact, Krasner's theoretical exposition of sovereignty in the international system explicitly seeks to dissociate the "organized hypocrisy" concept from the standard materialist dismissal of the power of social norms. But unfortunately he does not fully develop this distinction, and therefore his empirical analysis devolves into a simple litany of exceptions to the logic of appropriateness. Meanwhile, English School scholars' discussions of individual historical cases often point to material self-interest as a driver of leading states' decisions on recognition. But they have not integrated those empirical observations coherently into their theoretical models.

The two sides may also seem to be more at odds with each other than they really are, because many people misunderstand the meaning of the term "logic of appropriateness." The logic of appropriateness refers to a process of decisionmaking based on uncalculating obedience to behavioral norms, including decision rules and standard operating procedures, that are perceived as applicable to 
a given situation (Christensen 2011). The fact that obedience is uncalculated does not mean that the resulting behavior is necessarily contrary to the actor's selfinterest. Indeed, if the actor happened to ask why the norm must be obeyed, the standard answer would probably be that doing so is in his or her own best interest; think of a mother telling her son to brush his teeth. The key difference between the logic of appropriateness and the logic of consequences, then, lies not in the results of the behavior, but in the cognitive process that precedes the behavior. The logic of appropriateness involves a process of careful matching between the perceived situation and the proper behavioral norm, whereas the logic of consequences involves a process of comparative calculation of the potential utility of different behavioral courses of action in light of the perceived situation. Clearly, both of these cognitive processes could take place inside a state prior to the final recognition decision. There is ample room for a combination of the two logics.

To further explore the potential for a theoretical synthesis, take the general historical phenomenon that interests us here: 19th century Britain's policy on sovereign recognition. The British initially developed their policy in the 1820 s, due to the revolutionary tide that had just swept across Latin America. Suddenly having to deal with the proliferation of new political entities claiming sovereign status, Foreign Secretary George Canning asked British diplomats in the region to answer four basic questions (Pattison 1981):

1. Has the Government so constituted, already notified by a public act its determination to remain independent of Spain, and admit no terms of accommodation with the Mother Country?

2. Is it in military possession of the Country, and also in a respectable condition of military defense against any attack from Europe?

3. Does it appear to have acquired a reasonable degree of consistency and to enjoy the confidence and goodwill of several orders of the people?

4. Has it abjured and abolished the Slave Trade?

In Canning's view, if the political entity in question was a substantially independent, well-defended, and stable polity that respected the fundamental norms of Western "civilization" (as implied by the question about the slave trade), then it should be recognized as a sovereign state; but if not, then not.

Historians have generally interpreted Canning's four questions as an application of the logic of consequences (see, e.g., Manchester 1951). Not only did the four questions reflect a sense of the British national interest with respect to the emerging states of Latin America; in addition, Canning had to develop these criteria quickly in the face of a situation for which there was no settled behavioral 
norm-i.e., no clear logic of appropriateness-for Britain to follow. Therefore, the logic of consequences was primary.

But historians also teach us that after the Canning criteria were successfully applied to the Latin American countries, they became institutionalized inside the Foreign Office as the standard operating procedure for recognition decisions worldwide. The historian Wilfred Pattison writes that Canning's understanding of the "quasi-automatic nature of British recognition....set out the guide-posts for the British practice of recognition during the rest of the nineteenth century" (Pattison 1981, 34). The only major shift in Britain's standard criteria for recognition prior to World War I was that Canning's original question about popular "confidence and goodwill" gradually morphed into a focus on mere popular "obedience" - a less democratic concept, but also perhaps a more operationalizable one for the British diplomats who were tasked with making recognition recommendations (Pattison 1981, 40).

Thus, a set of decision rules that was initially produced according to the logic of consequences was subsequently applied according to the logic of appropriateness. Did Britain's reliance on such a rule-based approach systematically produce outcomes that were suboptimal for the British national interest? Hardly. Indeed, consistency in the application of these rules itself came to be seen as beneficial to the British national interest. In this way, the logic of appropriateness swings around and becomes the logic of consequences once again.

Given the interplay between the two logics, we should therefore seek to develop a coherent theory of recognition decisions that integrates both of them together. My hypothesis is that leading states should typically arrive at their recognition decisions via a two-step decisionmaking process. First, the logic of appropriateness delineates the set of states that should be recognized. Second, the logic of consequences determines how rapidly and smoothly the recognition of a given state actually takes place. In other words, if we think of recognition as a golf ball, standard norms of recognition -i.e., the logic of appropri-ateness - take it from the tee to the green. But the leading states' perceptions of self-interest-i.e., the logic of consequences - take it from the green to the cup. Both of these steps should typically be necessary for recognition to happen in any given case.

It is admittedly possible that some acts of recognition may occur (or fail to occur) without any serious calculation of material pros and cons. In golf, too, sometimes you can score a hole in one. But such cases should be highly unlikely, especially if the act of recognition is strongly contrary to the state's perceived selfinterest. Furthermore, it is possible that recognition may occasionally be granted (or refused) for preposterous and transparently selfish reasons. But such cases should become controversial in the international community—and especially so 
at times when liberal states are dominant. In consequence, the recognizing state would be shamed for the act, and its reputation would suffer.

\section{JAPAN FROM UNEQUAL TO EQUAL TREATIES}

I now turn to my case study of the sovereign recognition of Imperial Japan. Contributors to the recent IR literature on sovereign recognition have amply covered the cases of recognition of new states in Europe and Latin America during the long $19^{\text {th }}$ century. But they have had very little to say about how the old states of East Asia were treated during that same time period. 3 Meanwhile, the recent boom of IR research on East Asia's international history has devoted most of its attention to the dynamics of the traditional "Sinocentric" international system, rather than investigating the dynamics of the system that the West imposed in its place (Kang 2010; Johnston 2012). There is a gap here that needs to be filled.

The East Asian countries' road to sovereign recognition was long and arduous. After the West arrived in force in East Asia in the mid-19th century, those few countries that escaped the noose of formal colonization were subjected to a complex array of "unequal treaties" (Cassel 2012). Unequal treaties were imposed on the two most advanced states in the region, China and Japan, and on two geographically important buffer states, Siam and Korea. The unequal treaties severely limited the East Asians' exercise of core Westphalian state functions such as justice and border control and relegated them to the margins of international law and diplomacy. This was one short step away from what the political scientist Tanisha Fazal (2007) has termed "state death." Only Japan was able to escape the noose and gain formal Western assent to its full internal and external sovereignty - on a par with, say, Portugal or Peru - prior to World War I. Siam had to wait until the 1920s, and China had to wait until the 1940s. Meanwhile, Korea fell to the status of a colony. As the first non-Western state to make it fully into the Western "comity of nations," Japan's sovereign recognition by the West represents a major turning point in international history. 4 A careful study of the West's upward revision of the status of Japan may therefore also provide clues about the decision

${ }^{3}$ The two most powerful recent theoretical statements, Krasner (1999) and Fabry (2010), offer almost zero discussion of $19^{\text {th }}$ century East Asia. In a different article, Krasner (2001) discusses the Western refusal to extend sovereign status to the states of mid- $19^{\text {th }}$ century East Asia, but he does not seriously investigate why the West ended up granting it to Japan at the end of the century. A major exception to this rule is Kayaoğlu (2010). I discuss Kayaoglu's work in some detail below.

${ }^{4}$ Turkey gained Western acceptance of its international legal sovereignty in 1856 , but it was obligated to accept Western extraterritoriality privileges until 1923. See Kayaoğlu (2010). 
rules and practices that have driven Western recognition behavior more generally.

The unequal treaties system was imposed on Tokugawa Japan soon after the coerced opening of the country to trade in the early 1850 . The unequal treaties were similarly worded bilateral accords between Japan and each Western state. The first of these was the 1858 US-Japan Treaty of Amity and Commerce, and the second was the 1858 Anglo-Japanese Treaty of Edo. In subsequent years, other Western powers signed treaties with Japan that closely followed the US and UK model (Jones 1931). Japan was obliged to sign the unequal treaties under duress, and therefore it immediately started mounting diplomatic efforts to revise them (Auslin 2004). In addition to these efforts, starting in 1868 the new Meiji regime engaged in thoroughgoing domestic reforms, which many scholars argue were directly caused by the passion for overturning the treaties (e.g., Hirakawa and Wakabayashi 1989; Pyle 1989; Goto-Jones 2009).

What specific aspects of the unequal treaties made them so noxious to the Japanese? Perez (1999) highlights three issues especially: First, Japanese customs duties were fixed across the board at a maximum of $5 \%$ ad valorem - a very low level in international comparison. This placed a great burden on Japan's state finances. Second, all Westerners who were in Japan for any reason or length of time enjoyed the privilege of "extraterritoriality." Extraterritoriality meant that they were subject to the laws of their own country as enforced by their own consular courts, rather than the laws of Japan and the Japanese justice system. Civil as well as criminal cases pitting Westerners against Japanese were therefore adjudicated in the consular courts and exclusively in the Westerner's own language. This placed Japanese litigants at a severe structural disadvantage. In addition, some of the consular courts were very shoddily run. Sometimes the Western merchants themselves even moonlighted as judges. Japanese in Western countries did not enjoy these advantages. Third, the treaties created a number of "treaty ports." These were special areas for Western residence, which although not formally separated from the home territory nonetheless enjoyed broad powers of self-regulation and administration. In return, Western governments did accept restrictions on their citizens residing or traveling outside the treaty ports without special Japanese government permission. But given the principle of extraterritoriality, the Japanese found these provisions difficult to enforce. Furthermore, after 1881 the British government declared that its consular courts had the right to pursue fugitive offenders even beyond the borders of the treaty ports. Thus, for this purpose the British explicitly placed the entire country of Japan (as well as all others with whom similar treaty regimes applied) on a par with ordinary British imperial possessions (Jones 1931, 33-34).

The other major dilemma for the Japanese was that the unequal treaties were 
extremely difficult to change. They contained no provision for review, expiration, or termination, and they also featured a "most-favored nation" (MFN) clause. The MFN clause practically guaranteed the maintenance of a common Western front vis-à-vis Japanese demands for treaty revision. Japan tried various stratagems to convince individual Western states to break the common front, and sometimes it came close, but in the end the MFN clause allowed the West to hold firm. For instance, in 1888 Japan finally convinced one state, Mexico, to sign an equal treaty with it. In the treaty, Mexico gave up its extraterritoriality privileges in exchange for Mexican citizens receiving the rights to free travel, trade and residence in the Japanese interior. Mexico was an internationally recognized de jure sovereign state under international law, so signing an equal treaty with it was a victory for Japanese diplomacy. But in response to this breach of the common Western front, Britain and France immediately used the MFN clause to claim the rights that Japan had granted to Mexicans for their own citizens as well, in addition to maintaining their preexisting rights under the old treaties. In short, the MFN clause was like quicksand: the harder Japan tried to get out of its unequal situation, the deeper its subordination became (Jones 1931, 121). 5

As the 1890 opened, Japan's rise to full internal and external sovereignty still seemed a remote prospect (Perez 1999, 87-88). But in 1894, Japan achieved a surprising diplomatic breakthrough in secret negotiations with Great Britain: a new bilateral Treaty of Commerce and Navigation that placed the two states and their citizens on equal terms. In the new treaty, Britain promised to admit the Japanese courts' jurisdiction over its citizens, to close down its consular court system, and to accept the abolition of the special legal status of the treaty ports. This was to take place after a five year transition interval, during which Japan promised to institute a new Western-style legal civil code. In return, Japan gave British citizens the right to travel freely throughout the country, to lease (but not to own) land, and to continue the lucrative "coasting trade" of carrying domestic merchandise from port to port. It also agreed to join the international trademark and copyright convention. Finally, the two sides agreed to a new, differentiated and minutely detailed schedule of tariffs. For example, the old 5 percent ad valorem tariff was maintained for block, pig and slab tin, but a new 10 percent ad valorem tariff was applied to tin plates. The new tariffs were fixed for the 12-year duration of the treaty unless altered by mutual consent. In this one respect of mutual consent to tariff rate changes, the 1894 treaty can be said to have maintained a lin-

\footnotetext{
${ }^{5}$ Note that although the Western powers immediately claimed these rights for their citizens, they did not make strong moves to enforce their claims as they viewed the Mexico treaty as "practically harmless" (Perez 1999, 85).
} 
gering British finger on the scales of Japanese policy. But since the new treaty explicitly had a fixed duration of 12 years, after which point either party could denounce it, no one doubted that this was an equal treaty and that in signing it, Britain was fully recognizing Japan's sovereignty. ${ }^{6}$

Since Britain was the leading world power and the Western country that had the most citizens in Japan, conducted the most trade with Japan, and had been the greatest obstacle to previous attempts at treaty revision, the new AngloJapanese treaty broke the entire dam of the unequal treaty system. The other Western powers lined up to make equal treaties with Japan - although not always without attempting to claw back some special advantage for themselves, as will be discussed later in the article. As anticipated by the 1894 Anglo-Japanese treaty, the unequal treaties era formally ended in 1899.

\section{JAPAN'S WESTERNIZATION AS THE KEY TO SUCCESSFUL TREATY REVISION?}

To explain why Japan was able to achieve Britain's recognition of its full internal and external sovereignty in the 1890 s, let us first consider the relevance of the logic of appropriateness to this outcome.

Certainly, public statements on Japan's recognition by the Western officials of the day highlighted the logic of appropriateness. For instance, the German diplomat Baron Alexander von Siebold, who was deeply involved in the treaty revision issue, wrote in his 1901 book Japan's Accession to the Comity of Nations, "In the field of public law this is quite a new departure; but, more than this, it also marks a new epoch in the relations of West to East. This recognition of the justifiable claims of Japan had of course to be preceded by the triumph of European civilization over the pristine condition of affairs in that country" (von Siebold 2001 [1901], 3). One can find many similar quotations from British officials as well.

But such statements could have been mere public posturing, and today we have access to the internal state archives. So, when we look inside the machinations of the Foreign Office, do we find that Britain obediently applied Canning's rules for sovereign recognition to the case of Japan? To a large extent, yes. The first point to make here is that apart from some initial turbulence in the early days of the Meiji restoration, from the 1870 os onward Japan was evidently an independent, well-defended, and stable state. Therefore, in terms of the logic of appropriate-

\footnotetext{
${ }^{6}$ Japan ultimately won explicit British acknowledgment of its full tariff autonomy in a further treaty revision of 1911. See Hotta-Lister (1999).
} 
ness, the question of whether Japan deserved sovereign recognition boiled down to the question of whether it was sufficiently Westernized - or, in the terminology of the day, "civilized" (Gong 1984). And the more Meiji Japan Westernized, the more British officials warmed up to the idea of recognizing Japanese sovereignty.

The Far Eastern Consular Service of the British Foreign Office was a specially recruited and highly professionalized corps, with solid legal training as they had the responsibility of running the consular courts in addition to their other diplomatic duties. Right from the start of the Meiji period, these men conscientiously considered the question of whether or not Japan could be properly said to deserve sovereign recognition. And in line with the logic of appropriateness, already by the early 1880 s, consular officials such as the longtime Japan hand Sir Ernest Satow were not hesitating to admit that Japan's remarkable Westernization drive had put it on a glide path toward ultimately achieving full sovereign status (Brailey 1999, 34). But since they believed that Japan's Westernization was not yet complete or irreversible, they felt it necessary to obtain some kind of institutional guarantee of the provision of equal justice for foreigners who had to go before Japanese courts (Perez 1999). The British initially believed that this question could be relatively easily settled in diplomatic parleys, but the Japanese proved to be highly resistant to accepting any half-measures short of full sovereign recognition. As a result, despite many rounds of negotiations, the original, highly unequal treaties remained in place for much longer than most British diplomats thought appropriate.

The causal impact of Japan's Westernization efforts on British diplomats' attitudinal evolution on the recognition issue can be seen in the same diplomats' reactions to the entreaties of other East Asian states for the revision of their own unequal treaty regimes. For instance, when Satow became minister to Siam in 1885 , he was initially receptive to the idea of revising the Anglo-Siamese treaty, based on the evolution of his thinking about Japan. But after studying the matter on site, he concluded "that the Siamese were as yet unready to practice law in a way that would be satisfactory in the West" (Brailey 1999, 32). Similarly, an 1889 Foreign Office note entitled "Provisions for Abolition of Consular Jurisdiction" did not merely express openness to raising Japan's status, but also took pains to point out that such a decision would not require a parallel upgrade of China's, because "the Chinese Government would certainly be unwilling to make the changes in their laws and customs which must necessarily precede the abolition of Consular jurisdiction in China." 7 In line with the logic of appropriateness,

\footnotetext{
${ }^{7}$ Great Britain, Foreign Office, “Provisions for Abolition of Consular Jurisdiction,” June 19, 1889, in Nish $(1986,132-136)$.
} 
British diplomats considered a country's Westernization to be necessary for its admittance into the comity of nations, and therefore they were only willing to seriously consider opening the door to Japan.

The above-cited documents also indicate that British diplomats considered the rule of law to be the ultimate acid test of a state's Westernization. This finding meshes neatly with political scientist Turan Kayaoglu's (2010) more general argument that the key determinant of the end of extraterritoriality in states around the world was the reform of legal systems in line with Western modelswhat he calls "legal imperialism." Once Japan had achieved the rule of law, it was by definition "civilized" whether or not its ladies still wore kimonos. This standard of measurement removed a great deal of wiggle room for self-interested or simply ad hoc decisionmaking on sovereign recognition. Kayao glu's emphasis on the consistent Western focus on establishing proper legal institutions for achieving sovereign recognition fits neatly within the logic of appropriateness paradigm (see also Okagaki 2013).

The problem with Kayaoğlu's argument in the case of Japan, however, is that Britain suddenly gave up its demands for special guarantees of impartial justice and signed a new, fully equal treaty with Japan in 1894, five years before Japan's new law codes were unveiled in 1899. Admittedly the treaty's entry into force was linked to the arrival of the new codes, which is why Kayao glu is able to claim that the Japanese case fits his theory. But very importantly, the new treaty did not contain any British right of prior review or opt-out clause in the event that the Japanese legal codes were considered insufficient. Therefore the recognition goose was well and truly cooked, even though the Japanese themselves acknowledged as late as March 1894 that their efforts to prepare the new codes remained "in a backward state." 8 Clearly the British were bending their own rules for recognition, and many reasonable people were not convinced of the appropriateness of their decision. Indeed, Satow himself demurred, writing in a private letter to his colleague Frederick V. Dickins in 1889, "I feel pretty sure that our best policy is to be consistent, and to continue to say 'Show us first your codes.' We have been saying that for the past twenty years" (Ruxton 2008, 166). For their part, the Japanese were justified in considering such opinions to be overly legalistic and uncharitable. Satow was right, however, that the power of norms depends to a large extent on their consistent application. Yet for some reason the British suddenly became inconsistent.

The British volte-face took many other Western states by surprise as well. For

\footnotetext{
${ }^{8}$ Great Britain, Foreign Office, Fraser to Kimberley, March 27, 1894, in FO 46/435 (200-203), Nineteenth-Century Collections Online.
} 
example, in 1895 the Dutch prime minister Joan Roell told the British ambassador of his "doubts as to the prudence of the complete surrender that we had made to the Japanese in the question of extraterritoriality. It was possible, of course, that a few years hence their progress in civilization might be such as to justify the concession, but that remained yet to be shown."9 Roell was repeating the same line that British diplomats had long used on other Western states that had previously been tempted to recognize the sovereignty of Japan.

In sum, the logic of appropriateness argument provides essential clarification of Britain's decision to recognize Japan's sovereignty, but it is not the whole picture. Japan's thorough-going Westernization was necessary to put the question of full recognition in play; meanwhile, the much more modest Westernization of Siam and China put the recognition of those countries out of bounds. Even so, the logic of appropriateness argument does not explain the timing of Britain's recognition decision in 1894. Over many years of intensive treaty revision negotiations, Britain had firmly refused to accept Japanese demands for full sovereignty because of Japan's lack of Western-style law codes. But then in 1894, although Japan still had not written its new codes, Britain suddenly accepted the Japanese demand for full sovereignty.

Why did Britain change its mind? Japanese historians often argue that the British turnabout was due to masterful diplomacy by Japan's Foreign Minister Mutsu Munemitsu, ${ }^{10}$ and it does appear that Mutsu handled the matter quite well (Perez 1999). But this line of argument implies that Japan somehow outwitted Britain in the diplomatic chess game, and that is not credible. After all, the British Foreign Office was very happy with the final agreement. ${ }^{11}$ Instead, I hypothesize that Britain's changed perception of its material interests in Japan is what caused it to accelerate its recognition of the country in 1894 . The logic of appropriateness had done its work - the golf ball was on the green. It was now up to the logic of consequences to get the ball from the green to the cup.

\section{BRITISH NATIONAL INTERESTS AS THE KEY TO TREATY REVISION?}

The historian Ian Nish (2001 [1975]) has offered the most careful consideration

\footnotetext{
${ }^{9}$ Great Britain, Foreign Office, Rumbold to Kimberley, April 25, 1895, in FO 410/35 (29-30), UK National Archives.

${ }^{10}$ In this article I follow Japanese naming conventions, putting the family name first and the given name second.

${ }^{11}$ Bertie papers, Kimberley to Bertie, June 26, 1895, in ADD 63013, British Library.
} 
to date of the role of material incentives in Britain's decision to upgrade Japan's international status. Nish stresses that above all, "Britain acted from a sense of justice and out of a spirit of goodwill to the New Japan" - the normative logic of appropriateness. But in addition, he thinks that British self-interest consid-erations played a key supporting role in advancing Japan's cause. Since Nish is widely recognized as the leading historian of Britain's relations with Japan during the late $19^{\text {th }}$-early $20^{\text {th }}$ centuries, his judgment on this question is very important.

First, one might imagine that Britain changed its tune in 1894 because it wanted to forge a military alliance with Japan against a resurgent Russia. But Nish writes that this view is anachronistic. At the time the new treaty was signed, Britain was unsure whether Japan's military could even stand up against China, let alone against a genuine great power such as Russia. The Liberal government of the day therefore "had no thought of Japan as a possible ally" (Nish 2001 [1975], 20; Nish 1966, 37). Nish adds that "there is not a shred of evidence" that the Conservatives saw things any differently (Nish 1966, 41). ${ }^{12}$ Much the same can be said of the Foreign Office professionals. For instance, take the case of Sir Francis Bertie, who personally negotiated the Anglo-Japanese treaty of 1894 and later penned the first statement by a British official in favor of an exclusive alliance with Japan in 1901. Might not Bertie have already been thinking about alliance in 1894? In fact, Bertie's biographer stresses that it was not until Japan's victory over China in 1895 that he began to perceive "the desirability of keeping on good terms with "the Rising Power in the Far East" (Hamilton 1990, 26). Britain's decision to upgrade Japan's international status in 1894 was not driven by a desire to forge a military alliance with it.

Second, Nish also rejects the hypothesis that Britain upgraded Japan's international status in order to gain broad commercial advantages. Nish points out that the new treaty immediately raised tariffs on many goods and scheduled the ultimate return of full tariff autonomy to the Japanese, which would allow them to

12 This may be the right moment to point out that Britain's 1894 policy shift is also hard to explain as a result of ministerial changes. The Liberals and Conservatives traditionally had different outlooks on many foreign policy matters, but when the Liberals came back into power in 1892, the leading "Liberal Imperialist" Lord Rosebery became Foreign Secretary and by all accounts monopolized the government's handling of foreign policy issues (James 1963). The Liberal Imperialists essentially favored the Conservative foreign policy tradition of Disraeli and Salisbury over the Liberal foreign policy tradition of Gladstone. Then in March 1894, Rosebery rose to the position of Prime Minister and chose a close political ally, Lord Kimberley, as his successor at the Foreign Office. It was during Rosebery's tenure as Foreign Secretary that the decision was made to try to resolve the Japanese treaty revision issue, and it was during Kimberley's tenure that the resolution was achieved. In short, despite various governmental reshuffles, the same basic spirit guided British foreign policy (and especially Far Eastern policy) from at least the mid-1880s to the turn of the century. 
become as protectionist as they liked. Thus, however much goodwill the deal may have fostered, it was undoubtedly a step backward from the perspective of most British trading interests (Nish 2001 [1975], 16). Reinforcing Nish's point, it is well to note that the treaty revision negotiations were kept secret from the chambers of commerce and trade associations of British merchants in the Far East, and when the treaty was finally revealed, the merchants were outraged. As one contemporaneous source puts it, "The treaty was regarded by the entire foreign colony as a shameful sacrifice of British interests" (Annual Register 1895, 359). ${ }^{13}$

Third, Nish does argue that a defensive logic of commercial interest may have caused the British turnabout on the recognition issue. There was a growing perception in the Foreign Office that an increasingly nationalistic Japan might simply denounce the old treaty, as was being demanded by vocal street mobs. The old treaty had no provision for such an action, but the enforcement of Britain's treaty rights against a radicalized Japan would be difficult and costly. Therefore, many of the professional diplomats concluded that the wiser course was to move to negotiate a deal that cut their losses (Nish 2001 [1975], 13). In my own archival work I found considerable corroborating evidence for Nish's point. For instance, in a January 1894 letter to his fellow diplomat Cecil Spring-Rice, the longtime Japan hand Maurice de Bunsen wrote, "Much better to negotiate-unless the idea of T. R. [treaty revision] is given up altogether, but that would drive the Japs to desperation, and they would do something rash, curable only by gunboats. So go ahead, say I, despite of [the British merchant community in] Yokohama."14 Two weeks earlier, Spring-Rice had sounded a similar note in his influential recommendation to the Foreign Secretary on restarting treaty revision negotiations. ${ }^{15}$

But even while supporting this hypothesis on balance, Nish is unsatisfied with it. Is it really plausible to think that the leading world power would cave in so easily to the threats of an international non-entity - or more precisely, the street rabble of that non-entity? To the contrary, when the British agreed to restart treaty

${ }^{13}$ On the other hand, it is true that the London Times repeatedly accused the Foreign Office of undermining British trade with Japan by refusing to formally acknowledge the country's progress and thereby offending its delicate national sensibilities. See, e.g., "The Treaty Problem in Japan" (1886, 15). The Times may have been influenced by the money that the Japanese government was secretly funneling to its correspondents at the time (Mutsu 1983, 271 n. 18)

${ }^{14}$ Cecil A. Spring-Rice papers, de Bunsen to Spring-Rice, January 26, 1894, in CASR 1/5, Churchill Archives Center.

${ }^{15}$ In light of my later argument that the search for shipbuilding contracts may have played a decisive role in Britain's decision to recognize Japan, I might also note that in his memorandum entitled "Clan System in Japan," immediately after making his recommendation that Britain show flexibility in order to deflate the anti-foreign sentiment, Spring-Rice added that the Japanese government had just approved a major budget increase for the Navy. Great Britain, Foreign Office, "Clan System in Japan,” January 15, 1894, in FO 46/445 (28-29), Nineteenth Century Collections Online. 
revision negotiations in January 1894, their conclusion was simply that in light of the mounting difficulties with Japan "we should do wisely to move in a leisurely manner in the direction of negotiation." 16 This is hardly the language of panic. Moreover, once the negotiations started, as Nish notes, "They were determined not to make concessions under duress" (Nish 2001 [1975], 13). Indeed, during the course of the negotiations, the Japanese negotiator Viscount Aoki Shuzo did try to threaten to rip up the old treaty in a bid to accelerate progress, but the gambit backfired on him. Foreign Secretary Lord Kimberley described his reaction to Aoki's threat: "It was then impressed upon him that as Japan desired to enter the comity of Western nations, the Japanese Government must remember that one of the first principles of those States is the respect for Treaties, which cannot be revoked by one party merely because the Treaty provisions happen to be distasteful to it." 17 Similarly, Bertie, the main day-to-day British negotiator, always stayed "firmly in command of the talks" (Perez 1999, 137) by continually raising legal fine points or by feigning injury at one supposed slight or another, while making clear that if the Japanese did not behave properly the negotiations would be called off. The historian Oishi Kazuo (2008) affirms that from April 1894 onward, the British offered no significant concessions and the Japanese had to continually give in on all points of dissension in order to arrive at their final agreement in July of that year.

In sum, it is hard to believe that Britain's policy shift was solely driven by the desire to appease an increasingly uppity Japan. The Japanese certainly had some leverage in the negotiations because of their perceived potential to go rogue and denounce the treaties. But both sides also knew that if matters took such a turn, the British had what the strategists call "escalation dominance." The British therefore viewed the talks not merely as a means of cutting their losses, but also of extracting some significant benefit. As de Bunsen chirped when the treaty was actually signed in July 1894, "Now we ought to get anything we like out of Japan." ${ }^{18}$ So, what did they want - and did they get it?

${ }^{16}$ Great Britain, Foreign Office, "Memorandum by Mr. Bertie, with Minutes," January 12, 1894 (minutes from January 19), FO 46/455 (11), Nineteenth-Century Collections Online.

${ }^{17}$ Great Britain, Foreign Office, Kimberley to Fraser, in Nish (1986, 279-280).

18 Cecil A. Spring-Rice papers, de Bunsen to Spring-Rice, July 13, 1894, in CASR 1/5, Churchill Archives Center. 


\section{THE BRITISH DECISION AS SUPPORT FOR SHIPBUILDING INTERESTS?}

I contend that the British felt a new urgency to the question of recognizing Japan in the 1893-1894 time frame, because at that time the Imperial Japanese Navy (IJN) received a sharply increased budget for major foreign warship purchases, and the British wanted to win those contracts. My argument on this point is an innovation for the historical literature on this topic.

I should note from the outset that my archival research in the UK did not turn up a smoking gun that confirms an explicit recognition-for-ships quid pro quo between London and Tokyo. For instance, in a July 1894 personal letter to the Chancellor Sir William Harcourt, Foreign Minister Lord Kimberley gave a relatively detailed description of the terms of the just-signed treaty with Japan, but he did not mention the existence of any side deals on ships or anything else. ${ }^{19} \mathrm{On}$ the other hand, in light of British ideas about appropriate diplomatic behavior at that time, actually it would have been surprising if I had been able to find explicit documentation of a recognition-for-ships quid pro quo. From the $1830 \mathrm{~s}$ onward, support for "free trade" was at the heart of British foreign policy. Britain's free trade ideology was not just about opening up markets at home and abroad, but also about maintaining a rigid separation between business and the state: the doctrine of "laissez-faire" (Wallerstein 2011). The Foreign Office imbibed this doctrine deeply over the course of the Victorian era, developing a famously standoffish attitude toward the commercial sector (Platt 1968). Therefore, even as the wall of separation between British business and the state started to break down toward the end of the 19th century, there remained a kind of taboo on open discussions of the chase for contracts. For instance, in October 1895 the Japan-based sales agent for Armstrong's, a major English gun maker and naval shipbuilder, came to Satow-by then the top British diplomat in the country-to ask him to put in a good word with the Japanese government. In his diaries Satow writes,

Replied to him that I could not tout, as that wld. not be worthy of a great Power like England, but wld. drop a hint that the performances of the Yoshino at the Yalu fight had pleased English people very much, and that if the Japanese being of the same opinion as to the superior qualities of English-built ships, go to England for their new vessels, English nation will be gratified at this mark of appreciation of what they can do. So as to let Itō [Hirobumi] understand that I am not mere-

${ }^{19}$ Harcourt papers, Kimberley to Harcourt, July 13, 1894, MS Harcourt dep 51, Bodleian Library manuscripts. 
ly proudly indifferent (Ruxton 2010, 32).

That was salesmanship, Foreign Office-style. Given this context, we should not take the absence of frank discussion of a linkage between "high" diplomatic policy and "low" commercial interests as proof of the absence of such a linkage. And although there is no smoking gun here, there are plenty of shell casings lying about. $^{20}$

\section{THE BIG PICTURE}

To understand why Britain might have been motivated to make an implicit recognition-for-ships trade with Japan in 1894, it is first necessary to understand the bigger picture of British perceptions of their economic and geopolitical self-interest at that time.

First, on the economic side, starting in the 1870 s Britain had entered into a long period of relative economic stagnation, one of whose causes was the rise of determined competition in export markets from Germany, France, and the US (Hatton 1990). As the country's international competitiveness declined, British politicians started actively seeking to reverse the trend. In August 1885, in response to the lobbying efforts of the son of German Chancellor Otto von Bismarck on behalf of German companies in Japan, Prime Minister and Foreign Secretary Lord Salisbury cabled the British legation in Tokyo, "In cases where foreign Representatives interfere to the detriment of British commercial interests, you are at liberty to give the latter your support" (Platt 1968, 272). Salisbury's encouragement of active intervention on behalf of British merchants marked a sea change for British policy in the entire world. Despite Salisbury's intent, however, the "traditions of the British Foreign Service were too strong for pressure ever to be equally applied" (Platt 1968, 272). Indeed, a frustrated Salisbury himself ended up trying to carry out his own policy. In 1885, he agreed to a request from Armstrong's to personally promote its bid for a major Romanian government gun purchase (Bastable 2004, 217).

It is not coincidental that the first major case of British government intervention on behalf of the export interests of specific British companies would be on behalf of an armaments maker. Not only was the arms industry a large employer and major contributor to GDP, but in addition it was important for the country's military power. Therefore, although the British state generally avoided giving direct assistance to its declining industries during the latter part of the 19th century, it was much more active on behalf of the industries that directly supported

\footnotetext{
${ }^{20}$ Thanks to David Welch for suggesting this metaphor.
} 
the Royal Navy, which it viewed as the foundation of the British empire and even of modern civilization itself (Bastable 2004; R üger 2004).

These points lead us to the second, geopolitical side of British perceived selfinterest during this period. Britain was undoubtedly the leading world power during the second half of the $19^{\text {th }}$ century, but during the late 1880 s-early $1890 \mathrm{os}$ it started to wonder whether that lead was secure in the face of a resurgent France and Russia (Marder 1940; Kennedy 1976; Mullins 2000). In this context, British statesmen were greatly concerned by the rise of French naval shipbuilders as major competitors for business in the international market for warships.

For a long time, Britannia had ruled the waves in two senses - not only with its peerless navy, but also as the major producer of seagoing vessels sailing under any flag. In 1881, however, the French government revived its long-moribund shipbuilding industry with substantial subsidies, and in 1886 it removed its traditional prohibition on the export of guns. Meanwhile, it convinced French banks to assist the creation of a syndicate of shipbuilders in pursuit of foreign naval orders. Its highly accomplished diplomatic corps then helped the syndicate sell its products, and the banks invented the "tied loan" that obligated foreign governments to buy French ships in exchange for good terms on debt financing (Ropp 1987, 67-68).

The results of France's concerted efforts to raise its naval exports were spectacular (Ropp 1987, 69). Up until 1886, Britain had dominated the international market for warships. During the period from 1879-1886, it launched vessels for export weighing a total of nearly 58,000 tons, in contrast to Germany's 23,000 tons and France's measly 4,300 tons. By contrast, between 1887-1894, France's total rose to nearly 54,000 tons, while Britain's was just under 50,000, and Germany slipped back to 12,000. This reversal of fortune set alarm bells ringing not only among the British shipbuilders, but also in the halls of the state. The ship was soon righted; between 1895-1902, the British sold a remarkable 218,000 tons of warships, versus France's 47,400 and Germany's 42,000. The most important reason for this turnabout in British shipbuilders' fortunes was ship purchasing by Japan.

\section{SHIPS FOR JAPAN}

After the 1868 Meiji restoration, the Imperial Japanese Navy (IJN) modeled itself on Britain's Royal Navy and purchased its warships from Britain, too (Perry 1966). For a long time the IJN's fleet remained very small, but starting in the mid188 os its budget began to rise thanks to growing national wealth and rising nationalist sentiment. In 1884, in line with its past behavior, Japan placed orders with Armstrong's for two top of the line cruisers. But soon afterward, "French 
diplomats, the Paris banks, and the arms syndicate took it [Japan] right out of English hands" (Ropp 1987, 71). A key agent of this transformation was the French naval engineer Louis-Émile Bertin, who became the chief advisor at the Yokosuka naval yard in 1886 and actively promoted French naval theories and technologies. Indeed, the Japanese navy that defeated China in the 1894-95 war was largely Bertin's creation (Togari 1935).

British armaments makers cried foul as the French scooped up one naval contract after another in Japan in the late 1880s. Their cries caught the ear of Lord Salisbury, who wrote to the British legation in Tokyo in July 1887 to apply his 1885 rule of leveling the playing field for British business in pursuit of naval contracts. Here again we find Salisbury intervening on behalf of the armaments companies. But interestingly, the top British diplomat on the scene, Sir Francis Plunkett, rebuffed Salisbury's appeal. Plunkett wrote that Japan had made a strategic decision to reorient its entire navy toward the French model, which was reflected in its hiring of Bertin. "Under such circumstances," Plunkett wrote, "little or no diplomatic pressure is required to turn naval contracts towards France sooner than elsewhere. I fear, therefore, that I have no locus standi to make any useful representation on this point." 21

Plunkett knew that Japan's turn toward the French model for its navy was due in large measure to its frosty diplomatic relations with Britain at that time. A year earlier, attempting to follow through on Salisbury's policy of leveling the playing field, Plunkett had accused Prime Minister Ito of political favoritism in the railway contracting process and warned him that "continuance in the marked preference shown to Germany, so far from helping Treaty revision, must necessarily delay it." Ito had retorted that Britain's bid lost out to Germany's because Japan had felt "harshly and unfairly treated" by British diplomats. He was especially critical of Sir Harry Parkes, the long-serving (1865-1883) head of the British legation to the country, who had "repelled them by his criticisms and advice."22

Instead of Salisbury's confrontational approach, Plunkett's strategy for bringing the IJN back into the British fold was a charm offensive. In 1886, Japan's Navy Minister Saigo Tsugumichi was about to embark on a study tour to England and Europe. Plunkett wrote to London that it was important to roll out the red carpet for Saigo, to "secure the benefit of the political impression on Saigo's mind by our courteous treatment, and by the sight of our naval and mechanical resources,

\footnotetext{
${ }^{21}$ Great Britain, Foreign Office, Plunkett to Salisbury, July 10, 1887, in Nish $(1986,131)$.

${ }^{22}$ Great Britain, Foreign Office, Plunkett to Rosebery, March 1, 1886, FO 46/1-104 Vol. 343:62 (195-200), Nineteenth Century Collections Online. For the broader British-German commercial rivalry in Japan, see also Nish (2001 [1989], 55-56).
} 
while our shipbuilders and others will derive the commercial benefit of being the first to obtain his Excellency's attention."23 In a follow-up letter, Plunkett added that he had offered to provide a new infusion of British naval officers as instructors for the Naval College and new Naval Cadet School that Saigo intended to build. ${ }^{24}$ Saigo readily accepted the offer, and the British naval officer Captain John Ingles came to teach in Japan between 1887 and 1893. Ingles and the Frenchman Bertin quickly became engaged in a hot rivalry, intriguing on behalf of their respective countries' naval theories and technology (Dedet 1993). These British efforts were not without result. After being shut out of IJN purchasing since 1884, in 1891 Armstrong's finally secured a new contract for a protected cruiser (Brook 1999, 79). The British suppliers were back in the game. But as the IJN's budget remained small in international comparison, Ingles and Bertin were fighting over crumbs.

In August 1892, a new Japanese "national unity" government headed by Ito came into office with two principal objectives: treaty revision and a major naval buildup. The naval budget increase faced strong resistance from a majority of the members of the new, democratically elected Diet, but in February 1893 the IJN finally obtained sufficient funding for the purchase of Japan's first two heavy battleships, as well as various smaller vessels (Schencking 2002; Schencking 2005). Battleships were a real step up from anything Japan had purchased before. The weight of each was to be over 14,000 tons, as opposed to around 4,200 for the biggest protected cruiser (Brook 1999). The price was also heavy-around £1 million a copy, or $£ 2$ million overall. That figure was well over half of the entire average annual value of British exports to Japan during the 1890-1894 period ("Our Foreign Trade" 1896, 70-71).

The news that Japan had decided to start spending serious money on warships spread quickly not just among British shipbuilders, but also in British diplomatic circles. Cecil Spring-Rice notified the widely respected Conservative politician and foreign policy heavyweight George Curzon, "They seem to have a large amount of capital at their command - only of course it is silver not gold - they are now ordering ships in England I hope - two big battleships, which I trust will go to Armstrong's."25 Curzon's other main source on Japan, William Kirkwood, was just as excited as Spring-Rice but less sanguine. The previous year, Japanese anti-

${ }^{23}$ Great Britain, Foreign Office, Plunkett to Rosebery, June 30, 1886, FO 46/1-104 Vol. 345:1 (334-338), Nineteenth Century Collections Online.

${ }^{24}$ Great Britain, Foreign Office, Plunkett to Rosebery, July 10, 1886, FO 46/1-104 Vol. 346:49 (145-158), Nineteenth Century Collections Online.

${ }^{25}$ Curzon papers, Spring-Rice to Curzon, n.d. (spring 1893), in MSS EUR F 112, India Office files, British Library. 
British sentiment had been newly inflamed by the collision of an IJN vessel, the Chishima, with a British P\&O company mail steamer, the Ravenna. Japan was then pursuing a high-profile lawsuit against the $\mathrm{P} \& \mathrm{O}$ in the British consular courts (Roberts 2010). As a legal expert and former Crown Advocate in the Yokohama consular court, Kirkwood was very concerned about the case and its wider ramifications. He wrote to Curzon,

You can imagine how galling it is to the Crown (Japanese) to appear as a claimant in a foreign court within Japanese territory for a wrong done within such territory to its property by a foreigner. This ill feeling would be at any time very unfortunate, but it is doubly so at the present moment when the Navy Department has resolved to spend 15 million yen i.e. about $£ 2,000,000$ in the construction of two large men of war in Europe and are now discussing plans and so forth prior to determining where the contracts shall be placed. The Eastern mind is, as your experience will have taught you, frequently influenced by what appear to us petty considerations, and moves differently to that of the West. It would be grievous for British interests and trade for these contracts to be given to France or elsewhere..... ${ }^{26}$

Kirkwood's letter explicitly laid out the logic linking sovereign recognition to ship sales, but it is not quite a smoking gun for my hypothesis, because we do not know what Curzon did with Kirkwood's information.

It is important to stress that the British eagerness to sell ships to Japan was due not to national favoritism, but simply the impressive size of Japan's new naval budget. Britain was also eager to sell ships to Japan's rival China, for instance. In November 1893, both Foreign Secretary Lord Rosebery and Under-Secretary of State Sir Edward Grey privately notified the heads of Armstrong's and its competitor Hawthorn Leslie \& Co. that China might be gearing up to order some naval cruisers. Armstrong's boss, Sir Andrew Noble, wrote back to thank them for this information, adding that "although our own interest is the main spring, yet it is also of importance to the Country that such orders should be secured for England - they will give much employment, \& in the event of war, can be taken to increase the defensive power of this nation." 27

The final months of negotiations leading up to the 1894 treaty revision can be understood as a tango with the negotiations over the ship sales. In December

${ }^{26}$ Curzon papers, Kirkwood to Curzon, May 7, 1893, in MSS EUR F 112, India Office files, British Library. Underlining in original.

${ }^{27}$ Great Britain, Foreign Office, Noble to Grey, November 17, 1893, and Browne to Grey, November 18, 1893, in FO 800/36.3 
1893 and January 1894, the Japanese preferentially solicited selected British companies to make formal tender offers for the two heavy battleships. This was followed rapidly by the January 1894 Foreign Office decision to restart treaty revision negotiations. ${ }^{28}$ Yet much uncertainty still remained in both Tokyo and London about whether either deal would ever materialize. The British were particularly skillful at finding excuses to stretch things out, a strategy that produced increasingly substantial Japanese concessions on many matters. On May 7, Aoki had yet another disappointing meeting with Bertie, who relayed various concerns about the draft treaty and suggested that the Board of Trade might have more concerns once it finished its analysis. ${ }^{29}$ Interestingly, on the very same day, Aoki frantically telegraphed to Foreign Minister Mutsu to "strongly recommend Government to shorten completion of ironclads" and to obtain any "necessary consent of Parliament in this session." 30 Mutsu forwarded Aoki's message to Navy Minister Saigo Tsugumichi, who wrote back immediately that the IJN was determined to purchase one ship each from Armstrong's and from Thames Iron Works. Mutsu then confirmed the IJN's decision in a telegram to Aoki on May $16 .{ }^{31}$ At the same time, Armstrong's emissary Saxton Noble telegraphed joyfully back from Japan that he had gained Japan's approval to build one of the two new battleships (M ünter 1915, 171). The contract with Armstrong's was formalized at the end of May, and then the Thames Iron Works contract for the second battleship came through in early June ("Thames Built Battleships" 1897, 341-345). At the same time, the treaty revision negotiations started speeding up again. The new Anglo-Japanese treaty was formally signed on July 16, despite the deteriorating situation in Korea, and ratification took place in August (Perez 1999). The Foreign Office had led the matter from start to finish, and there was no debate on the treaty either in Cabinet or in Parliament.

For France and Germany, the announcement of the secretly negotiated AngloJapanese treaty was an unwelcome surprise. They had long tried to use the car-

${ }^{28}$ Preferentially: Japan, Navy Ministry, "New Warship Building Documents,” June 22, 1893, JACAR Ref. C11081498300; Tender offers: Vickers papers, "Report to Meeting of Directors to be held in London on Tuesday, January 25, 1894," Vickers 1157, Cambridge University Library; Restart negotiations: Great Britain, Foreign Office, "Memorandum by Mr. Bertie, with minutes" January 12, 1894 (minutes from January 19), FO 46/445 (11), Nineteenth Century Collections Online.

${ }^{29}$ Great Britain, Foreign Office, "Memorandum of Interview held at Foreign Office on May 7 , 1894," FO 46/445 (195-196), Nineteenth Century Collections Online.

${ }^{30}$ Aoki's overt reason for making this recommendation was to avoid work stoppages due to Britain's increasingly poor labor relations. Japan, Foreign Ministry, Aoki to Mutsu, May 8, 1894, JACAR Ref. B0709036100o. Note that May 7 in the UK would be May 8 in Japan.

${ }^{31}$ Japan, Foreign Ministry, Saigo to Mutsu, May 8, 1894 and Mutsu to Aoki, May 16, 1894, JACAR Ref. Bo7090361000. 
rot of ostensibly greater flexibility on treaty revision as a means of gaining commercial advantage over the British. Now they could no longer play that game. Nevertheless, Japan still needed to sign equal treaties with all the powers in order to fully escape its second-class international status. Therefore both France and Germany retained some leverage, and they made sure to use it.

In April 1896, after much wrangling, the governments of France and Japan secretly made an explicit ships-for-recognition agreement (Sims 1998, 174). The French had been pushing this line steadily since at least 1894. In June 1896, the Japanese placed an order for a protected cruiser (what was to become the "Azuma") and four small torpedo boats with the French Sociéte des Forges et Chantiers de la Méditerranée, and then in August the new Franco-Japanese treaty was completed. ${ }^{32}$ The Azuma was the last big ship that France would ever build for Japan.

Germany behaved in much the same manner. In June 1895, the British diplomat Gerard Lowther wrote back to London, "I gather they [Japan] have more or less decided to spend 41/2 millions on ships in England, and they expect to be obliged to order one in Germany as the price for the signature of the Treaty with that country."33 In March 1896, Satow learned that "Germans are holding out for an order for an ironclad and a cruiser before they will consent to sign the Treaty" (Ruxton 2010, 73). In the end, Japan and Germany agreed on a new equal treaty on April 4, 1896, and then agreed on the construction of a protected cruiser (the "Yakumo") by the AG Vulkan shipyard in Stettin. The Yakumo was the only big ship that Germany would ever build for Japan.

So in the end the French and the Germans had their pound of flesh. 34 The strong insistence of France and Germany on explicit recognition-for-ships deals increases the plausibility of my claim that such a deal was implicit in the British recognition of Japan, too.

Britain's timely recognition of Japan ended up benefiting its economy far more than anyone could have imagined at the time the revised treaty was signed. After the 1895 war, the Japanese used most of the huge war indemnity from China to buy more warships from Britain (Schencking 2005). 35 Moreover, on top of the

${ }^{32}$ Sims (1998) notes that the agreement was so sensitive on the Japanese side that no evidence of it has ever turned up in the Japanese archives. It is only thanks to the French side that we know about it. This reinforces the point made earlier about how unlikely it would be to find evidence of a similar agreement between Japan and Britain, even if one really had been made.

${ }^{33}$ Kimberley papers, Lowther to Kimberley, June 1895, Ms Eng c4382, Bodleian Library manuscripts.

${ }^{34}$ But note that even for these ships, the Japanese insisted on installing guns from Armstrong's (Evans and Peattie 1997, 62). 
indemnity, Japan broke its long-held policy of exclusive reliance on indigenous finance to borrow money in the City of London for even more naval expansion. As a result of this increased spending, the IJN was transformed and British corporate coffers enriched (Brook 1999). Later the Japanese started building the ships themselves, but still under license from Armstrong's or its major British competitor, Vickers. Meanwhile it started to produce its guns and ordnance at the Japan Steel Works, a joint venture between Armstrong's, Vickers and the Hokkaido Coal and Steamship Company that was created in 1907 (Conte-Helm 1994; Matsumoto 2006). In addition to the financial profits that the British drew from these arrangements, Anglo-Japanese economic collaboration would turn out to be a key support for the formal military alliance that the two countries maintained from 1902 onward (Davis 2008/9).

\section{CONCLUSION}

In this article, I have argued that instead of viewing the logic of appropriateness and the logic of consequences as competing hypotheses for understanding state decisionmaking on sovereign recognition, we need a theoretical synthesis between the two. The logic of appropriateness and logic of consequences are not polar opposites, but rather represent two separate cognitive processes that leading states engage in when faced with the question of granting recognition. My proposed synthetic hypothesis suggests that the two logics work in sequence. First, leading states use the logic of appropriateness to delineate the set of states that should be recognized. Second, they use the logic of consequences to determine how rapidly and smoothly the recognition of a given state actually takes place.

The value of this proposed theoretical synthesis is indicated by the historical case of Great Britain's recognition of Japan in the 19th century, an important test case for broader theories of recognition. Japan's dramatic Westernization from the 1870 s onward created a strong presumption in the West that it deserved an upgrade in its international status, but the British ultimately required sufficient material incentives to give Japan that upgrade. I have laid particular emphasis on the causal importance of Japan's greatly increased budget for naval ship purchases in the 1893-1894 time period. The pursuit of naval warship exports appears to have helped Britain overcome its remaining legalistic doubts about the appropriateness of sovereign recognition. In other words, Britain recognized

\footnotetext{
${ }^{35}$ Interestingly, China's war indemnity was financed by France and Russia, but still Japan deposited the money in London and ended up buying mostly British merchandise.
} 
Japan upon realizing that it would do well by doing good.

I conclude with two important caveats. First, there are severe limits to the generalizability of results from a single-case study. Conscious of this fact, in addition to the Britain-Japan story, this article has also cast glances at British thinking about the recognition of other East Asian states, and at French and German thinking about the recognition of Japan. I have argued that these other cases seem to reinforce the main message of the article, but it would be beneficial in the future to compare them much more fully.

Second, this article has focused on a case prior to World War I and the dramatic Wilsonian transformation of the fundamental norms of international society (Manela 2007). In particular, under the post-1918 norm of national self-determination, sovereign recognition could now be offered to a "nation" even if it had only the barest façade of a state organization. ${ }^{36}$ But "nations," much more than "states," are often in the eye of the beholder. This much greater vagueness in the concept of what it is that needs to be recognized would seem to open up much more room for motivated bias or "organized hypocrisy" in the post-World War I era. Therefore, whatever the generalizability of the findings from the Japan case to other pre-World War I cases, I would caution that there is no reason to assume that the Japan model should generalize to the post-World War I era. But again, this is a matter that will have to be left to further research.

\section{REFERENCES}

\section{ARCHIVAL HOLDINGS}

N.B.: Full references to specific primary documents are provided in the text. Bertie papers, Western manuscripts collection, British Library (London, UK). Cecil A. Spring-Rice papers, Churchill Archives Center, Churchill College, Cambridge University (Cambridge, UK)

Curzon papers, India Office files, British Library (London, UK).

Great Britain, Foreign Office (FO) records, UK National Archives (Kew, UK).

Harcourt papers, Bodleian Library manuscripts collection, Oxford University (Oxford, UK).

Japan, Foreign Ministry records, Japan Center for Asian Historical Records (JACAR), National Archives of Japan (Tokyo, Japan). Accessed at http://www.jacar.go.jp

\footnotetext{
${ }^{36}$ Fabry (2010) argues that this norm only fully came into force after World War II.
} 
Japan, Navy Ministry records, Japan Center for Asian Historical Records (JACAR), National Archives of Japan (Tokyo, Japan). Accessed at http://www.jacar.go.jp

Kimberley papers, Bodleian Library manuscripts collection, Oxford University (Oxford, UK).

Nineteenth Century Collections Online database, accessed through USC Libraries system.

Vickers papers, Cambridge University Library manuscripts collection (Cambridge, UK).

\section{SECONDARY SOURCES}

Agné, Hans and Jens Bartelson, Eva Erman, Thomas Lindemann, Benjamin Herborth, Oliver Kessler, Christine Chwaszcza, Mikulas Fabry and Stephen D. Krasner. 2013. "Symposium: The Politics of International Recognition." International Theory 5(1), 94-176.

Auslin, Michael R. 2004. Negotiating with Imperialism: The Unequal Treaties and the Culture of Japanese Diplomacy. Cambridge, MA: Harvard University Press.

Bastable, Marshall J. 2004. Arms and the State: Sir William Armstrong and the Remaking of British Naval Power, 1854-1914. Aldershot, UK: Ashgate.

Brailey, Nigel. 1999. "Ernest Satow and the Implementation of the Revised Treaties in Japan.” In The Revision of Japan's Early Commercial Treaties, Suntory Centre Discussion Paper No. IS/99/377, London, UK: London School of Economics, 25-38.

Brook, Peter. 1999. Warships for Export: Armstrong Warships 1867-1927. Gravesend, Kent, UK: World Ship Society.

Bull, Hedley and Adam Watson eds. 1984. The Expansion of International Society. Oxford, UK: Oxford University Press.

Cassel, Par Kristoffer. 2012. Grounds of Judgment: Extraterritoriality and Imperial Power in Nineteenth-Century China and Japan. Oxford, UK: Oxford University Press.

Christensen, Tom. 2011. "Logic of Appropriateness." In B. Badie, D. BergSchlosser and L. Morlino ed., International Encyclopedia of Political Science. Thousand Oaks, CA: SAGE Publications, 1474-1477.

Conte-Helm, Marie. 1994. "Armstrong's, Vickers and Japan.” In Ian Nish ed., Britain and Japan: Biographical Portraits 1, Folkestone, Kent, UK: Japan Society, 92-105.

Davis, Christina L. 2008/9. "Linkage Diplomacy: Economic and Security Bargaining in the Anglo-Japanese Alliance, 1902-23." International 
Security 33(3), 143-179.

Dedet, Christian. 1993. Les fleurs d'acier du Mikado. Paris: Flammarion.

Evans, David C. and Mark R. Peattie. 1997. Kaigun: Strategy, Tactics, and Technology in the Imperial Japanese Navy 1887-1941. Annapolis, MD: Naval Institute Press.

Fabry, Mikulas. 2010. Recognizing States: International Society and the Establishment of New States Since 1776. New York: Oxford University Press.

Fazal, Tanisha. 2007. State Death: The Politics and Geography of Conquest, Occupation and Annexation. Princeton: Princeton University Press.

Gong, Gerrit W. 1984. The Standard of "Civilization" and International Society. Oxford, UK: Clarendon Press.

Goto-Jones, Christopher. 2009. Modern Japan: A Very Short Introduction. Oxford, UK: Oxford University Press.

Hamilton, Keith. 1990. Bertie of Thane: Edwardian Ambassador. Woodbridge, Suffolk, UK: The Royal Historical Society, The Boydell Press.

Hatton, T.J. 1990. "The Demand for British Exports, 1870-1913." The Economic History Review, New Series 43(4), 576-594.

Hirakawa, Sukehiro and Bob Tadashi Wakabayashi. 1989. "Japan's Turn to the West." In Marius Jansen ed., The Cambridge History of Japan 5. Cambridge: Cambridge University Press, 432-498.

Hotta-Lister, Ayako. 1999. "The Anglo-Japanese Treaty Revision of 1911." In The Revision of Japan's Early Commercial Treaties. Suntory Centre Discussion Paper No. IS/99/377, London, UK: London School of Economics, 38-53.

Hui, Victoria Tin-Bor. 2005. War and State Formation in Ancient China and Early Modern Europe. New York: Cambridge University Press.

James, Robert Rhodes. 1963. Rosebery. London: Weidenfeld and Nicolson.

Johnston, Alastair Iain. 2012. "What (If Anything) Does East Asia Tell Us About International Relations Theory?" Annual Review of Political Science 15(1), 53-78.

Jones, Francis Clifford. 1931. Extraterritoriality in Japan and the Diplomatic Relations Resulting in its Abolition, 1853-1899. New Haven: Yale University Press.

Kang, David C. 2010. East Asia before the West: Five Centuries of Trade and Tribute. New York: Columbia University Press.

Kayaoglu, Turan. 2010. Legal Imperialism: Sovereignty and Extraterritoriality in Japan, the Ottoman Empire, and China. Cambridge, UK: Cambridge University Press. 
Kennedy, Paul M. 1976. The Rise and Fall of British Naval Mastery. London: A. Lane.

Krasner, Stephen D. 1999. Sovereignty: Organized Hypocrisy. Princeton: Princeton University Press.

Krasner, Stephen D. 2001. "Organized Hypocrisy in 19th Century East Asia." International Relations of the Asia-Pacific 1(2), 173-197.

Krasner, Stephen D. 2013. "Recognition: Organized Hypocrisy Once Again." International Theory 5(1), 170-176.

Manchester, Alan K. 1951. "The Recognition of Brazilian Independence.” The Hispanic American Historical Review 31(1), 80-96

Manela, Erez. 2007. The Wilsonian Moment: Self-Determination and the Origins of Anticolonial Nationalism. Oxford, UK: Oxford University Press.

Marder, Arthur J. 1940. The Anatomy of British Seapower: A History of British Naval Policy in the Pre-Dreadnought Era, 1880-1905. New York: Knopf.

Matsumoto, Miwao. 2006. Technology Gatekeepers for War and Peace: British Ship Revolution and Japanese Industrialization. Houndmills, UK: Palgrave Macmillan.

Mullins, Robert E. 2000. "Sharpening the Trident: The Decisions of 1889 and the Creation of Modern Seapower." Doctoral Dissertation. King's College, London.

Munter, Balthasar. 1915. Nogle Erindringer. Gyldendal, Denmark: Nordisk Forlag.

Mutsu, Munemitsu ed. 1983. Kenkenroku: A Diplomatic Record of the SinoJapanese War, 1894-95(ed. and trans. by Gordon Mark Berger). Princeton and Tokyo: Princeton University Press and Tokyo University Press for the Japan Foundation.

Nish, Ian ed. 1986. British Documents on Foreign Affairs: Reports and Papers from the Foreign Office Confidential Print, Part I, Series E (Asia, 18601914), Vol. 3: Japanese Treaty Revision, 1878-1894. New York: University Publications of America.

Nish, Ian. 1966. The Anglo-Japanese Alliance: The Diplomacy of Two Island Empires 1894-1907. London: The Athlone Press.

Nish, Ian. 2001 [1975]. "Japan Reverses the Unequal Treaties: The AngloJapanese Commercial Treaty of 1894." In Collected Writings of Ian Nish, pt. 1. Tokyo: Edition Synapse.

Nish, Ian. 2001 [1989]. “Japan's Modernization and Anglo-German Rivalry in the 1880s." In Collected Writings of Ian Nish, pt. 2. Tokyo: Edition Synapse.

Oishi, Kazuo. 2008. Jouyaku Kaisei Koushoushi (History of Negotiations over Treaty Revision) 1887-1894. Kyoto: Shibunkaku. 
Okagaki, Tomoko. 2013. The Logic of Conformity: Japan's Entry into International Society. Toronto: University of Toronto Press.

“Our Foreign Trade: Its Progress, State, and Dangers." 1896. Investors' Review (London) 7(34), 5-71.

Pattison, Wilfred Keith. 1981. "The International Law of Recognition in Contemporary British Foreign Policy.” Ph. D Dissertation, University of Virginia.

Perez, Louis G. 1999. Japan Comes of Age: Mutsu Munemitsu and the Revision of the Unequal Treaties. London: Associated University Presses.

Perry, John Curtis. 1966. "Great Britain and the Emergence of Japan as a Naval Power." Monumenta Nipponica 21(3-4), 305-321.

Platt, D.C.M. 1963. "The Role of the British Consular Service in Overseas Trade, 1825-1914." The Economic History Review, New Series 15(3), 494-512.

Platt, D.C.M. 1968. Trade, and Politics in British Foreign Policy, 1815-1914. Oxford, UK: Clarendon Press.

Pollard, S. 1952. "Laissez-Faire and Shipbuilding" The Economic History Review 5(1), 98-115.

Pyle, Kenneth. 1989. “Meiji Conservatism." In Marius Jansen ed., Cambridge History of Japan 5. Cambridge: Cambridge University Press, 674-720.

Roberts, Christopher Keepfer. 2010. "British Extra-Territoriality in Japan, 18591899." Doctoral dissertation. School of African and Oriental Studies, University of London.

Ropp, Theodore. 1987. The Development of a Modern Navy: French Naval Policy 1871-1904. Annapolis, MD: Naval Institute Press.

Ruger, Jan. 2004. "Nation, Empire, and Navy: Identity Politics in the United Kingdom, 1887-1913." Past and Present 185(1) , 159-187.

Ruxton, Ian ed. 2008. Sir Ernest Satow's Private Letters to W. G. Aston and F. $V$. Dickins: The Correspondence of a Pioneer Japanologist from 1870 to 1918. Morrisville, NC: Lulu Press e-book.

Ruxton, Ian ed. 2010. The Diaries of Sir Ernest Satow, British Minister in Tokyo (1895-1900): A Diplomat Returns to Japan. Morrisville, NC: Lulu Press e-book.

Schencking, J. Charles. 2002. "The Politics of Pragmatism and Pageantry: Selling a National Navy at the Elite and Local Level in Japan, 1890-1913." In Sandra Wilson ed., Nation and Nationalism in Japan. New York: Routledge Curzon, 21-37.

Schencking, J. Charles. 2005. Making Waves: Politics, Propaganda, and the Emergence of the Imperial Japanese Navy, 1868-1922. Stanford, CA: Stanford University Press. 
Sims, Richard. 1998. French Policy toward the Bakufu and Meiji Japan, 1854-95. Richmond, UK: Japan Library.

Suzuki, Shogo. 2009. Civilization and Empire: China and Japan's Encounter with European International Society. New York: Routledge.

“Thames Built Battleships.” 1897. Engineering 63 (March 12), 341-345.

The Annual Register: A Review of Public Events at Home and Abroad for the Year 1894. 1895. London: Longmans, Green, and Co.

"The Treaty Problem in Japan." 1886. The Times (March 6), 15.

Togari, Capitaine de vaisseau. 1935. Louis-Emile Bertin: son role dans la creation de la marine Japonaise. Paris: Charles-Lavauzelle \& Cie.

von Siebold, Baron Alexander. 2001 [1901]. Japan's Accession to the Comity of Nations. Reprint edition. New York: Routledge.

Wallerstein, Immanuel. 2011. The Modern World-System IV: Centrist Liberalism Triumphant, 1789-1914. Berkeley, CA: University of California Press. 